Review

\title{
Interaction between the Circadian Clock and Regulators of Heat Stress Responses in Plants
}

\author{
Tejasvinee Mody ${ }^{+}$, , Titouan Bonnot $^{+}(\mathbb{D})$ and Dawn H. Nagel ${ }^{*}$ \\ Department of Botany and Plant Sciences, University of California, Riverside, California 92507, CA, USA; \\ tmody001@ucr.edu (T.M.); tbonnot@ucr.edu (T.B.) \\ * Correspondence: dawnn@ucr.edu; Tel.: +1-951-827-4425 \\ + Equal contribution.
}

Received: 2 January 2020; Accepted: 29 January 2020; Published: 1 February 2020

\begin{abstract}
The circadian clock is found ubiquitously in nature, and helps organisms coordinate internal biological processes with environmental cues that inform the time of the day or year. Both temperature stress and the clock affect many important biological processes in plants. Specifically, clock-controlled gene regulation and growth are impacted by a compromised clock or heat stress. The interactions linking these two regulatory pathways include several rhythmic transcription factors that are important for coordinating the appropriate response to temperature stress. Here we review the current understanding of clock control of the regulators involved in heat stress responses in plants.
\end{abstract}

Keywords: circadian clock; heat stress; thermotolerance; transcription factors; rhythmic gene expression

\section{Introduction}

The negative impacts on plant growth and development sustained from increasing environmental temperatures necessitate a comprehensive understanding of the underlying molecular and physiological interactions and mechanisms [1,2]. To adapt to changing environmental temperatures, plants take advantage of multiple regulatory and signaling pathways to optimize growth and fitness [3-6]. One such signaling pathway is known as the circadian clock-endogenous time-keeping machinery that accurately and precisely coordinates internal processes depending on the external surroundings [7-12]. The clock acts as a molecular switch, turning genes on or off when conditions are more or less favorable or when something requires an immediate response, primarily by regulating those genes' transcription [13]. More broadly, the thermal effects on growth and fitness for some plants differ between day and night [14]. This is evident even in crop varieties with different sensitivity to heat stress, such as rice [15]. Therefore, insights into day versus night temperature stress responses, and more specifically time-of-day effects during the $24 \mathrm{~h}$ period, is critical for the accurate prediction of the appropriate molecular response to changing weather patterns for a variety of plants.

In Arabidopsis, where our understanding of the plant clock is most comprehensive, components of the oscillator interact at the transcriptional, post-transcriptional, and translational level to sustain robust $\sim 24 \mathrm{~h}$ oscillations (rhythms) [16,17]. At the core are two MYB transcription factors (TFs), CIRCADIAN CLOCK ASSOCIATED1 (CCA1) and LONG HYPOCOTYL (LHY), as well as a member of the pseudo-response regulators (PRRs), TIMING OF CAB EXPRESSION1 (TOC1) [18]. CCA1 and LHY show peak (highest) expression in the morning and repress TOC1; thus, TOC1 expression is partitioned to the evening [19]. TOC1 in turn regulates the expression of CCA1 and LHY, forming the core clock feedback loop [20,21]. Throughout the day/night cycle, the core loop regulates and contributes to the timing of peak expression for other primary clock components (Figure 1) [22-28]. For example, in the morning and during the day, additional loops composed of CCA1, LHY, PRR7, and PRR9, and in the 
evening, components of the evening complex (EC), all play critical roles in sustaining normal clock function [25-27].

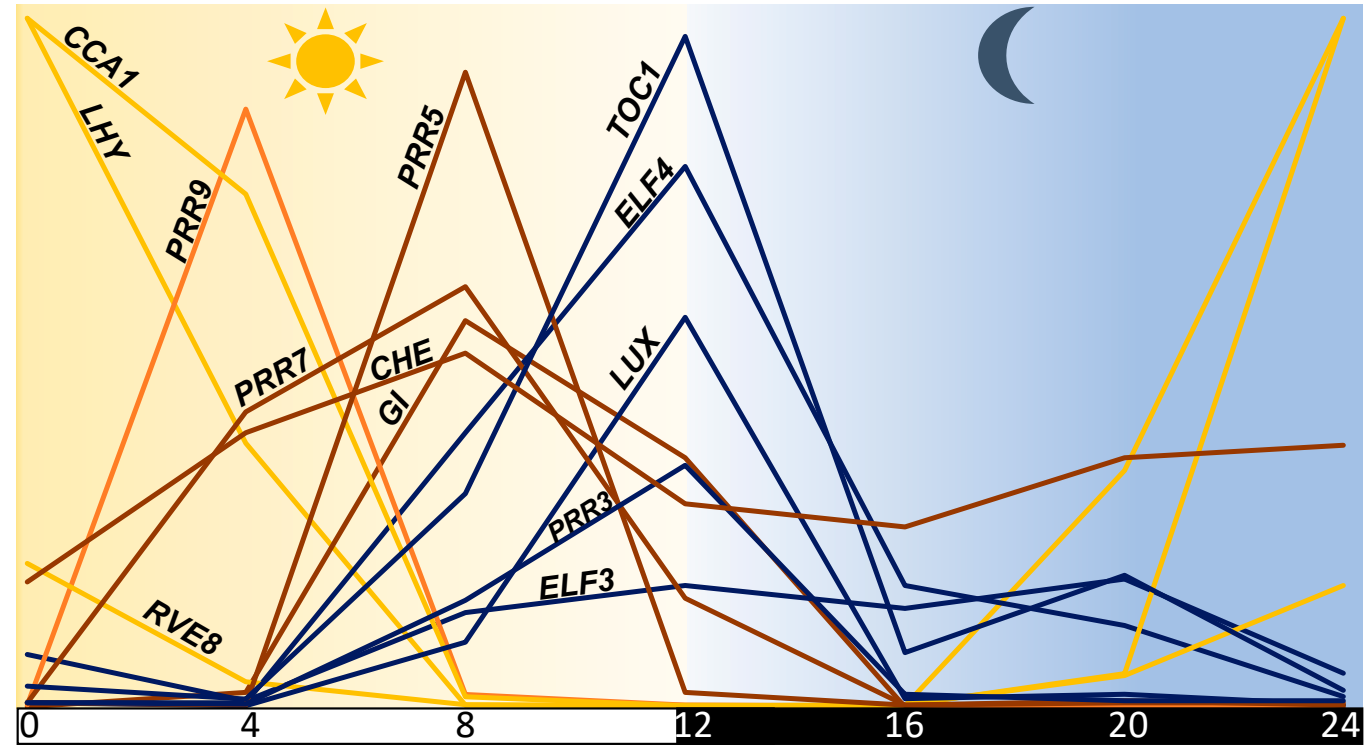

\section{Time of day (h)}

Figure 1. Timing of the peak expression of primary circadian clock components. Represented are normalized expression profiles obtained from DIURNAL, using experimental conditions LDHH_SM and LDHH_ST [29].

Coordination between clock components and environmental signals, such as light and temperature, contribute to clock robustness and optimal plant growth [8-10,30-33]. In Arabidopsis, a greater understanding of the interaction between light signals and the clock is known [33]. However, the relationship status between temperature and the clock is complicated. Within the range of physiologically relevant temperatures $\left(\sim 12-32^{\circ} \mathrm{C}\right)$, the clock can be entrained by cycles of hot and cold, but will buffer against prolonged temperature changes to maintain a $\sim 24 \mathrm{~h}$ periodicity, referred to as compensation [30,34-36]. CCA1, LHY, PRR7, and PRR9, along with a few other components, have been implicated in the regulation of entrainment and compensation depending, on the temperature range $[11,24,36,37]$. In addition, TOC1 and the photoreceptor phytochrome B (PHYB) have also been linked to high ambient (warm) temperature signaling in the clock [38-40]. Together, warm temperatures impact multiple levels of gene regulation, including alternative splicing, post-translation, and protein abundance $[12,34,41,42]$. More recently, it has been shown that the impact on the transcript abundance of clock genes following a $1 \mathrm{~h}$ exposure to $30{ }^{\circ} \mathrm{C}$ differs depending on the time of day [43]. Circadian gating (controlling the magnitude or the occurrence of a response based on time of day) of cold responses for clock and clock-controlled genes have been previously reported [44]. Furthermore, the cold induction of several TFs is dependent on time of day [44-46]. Therefore, crosstalk between heat- and cold-gated responses is likely to intersect for several clock and clock controlled genes. Interestingly, the binding of CCA1 to clock targets is enhanced at a high ambient temperature $\left(\sim 30^{\circ} \mathrm{C}\right)$ while the opposite effect is observed for the evening clock components association with their targets $[47,48]$. Members of the heat shock protein family (HSP90.2) also contribute to the adjustment of the circadian period in warm-cold-entrained seedlings [49]. However, the precise mechanisms of how the clock maintains this remarkable balance between sensitivity and resistance to changes in ambient temperatures at the molecular level remains poorly understood in plants and many other organisms. Several insightful reviews have been written on how high ambient temperature interacts with the clock in plants $[6,11,12,30]$. This review primarily focuses on how temperatures outside the range of compensation (heat stress) impact the expression of clock genes and clock-controlled TFs. 


\section{Regulation of Clock Genes by Heat Stress in Plants}

Outside the range of compensation, exposure to extreme temperatures alters clock gene expression, and thus clock-controlled processes [50-53]. Up to 50\% of the genes responsive to temperature stress show diurnal or circadian oscillations in Arabidopsis [53]. It is therefore not surprising that together, heat stress and the clock significantly influence how plants interact with a changing environment. Mutants for several clock components impact the plant's ability to tolerate and acclimate to temperature stress [13,54-58]. In addition, recent studies indicate that the F-box protein ZEITLUPE (ZTL) and HSP90.2 are required for proper clock function under heat stress, as they modulate protein quality control [51].

Emerging transcriptome studies suggest that during the day, the plant transcriptional response to heat stress is quite dynamic [50,59]. In Arabidopsis, the transcript abundance of clock genes is altered in response to heat stress depending on the time of day [50] (Figure 2). CCA1, PRR7, PRR9, and other primary components show increased mRNA abundance to heat stress, with greater induction occurring at specific times of the day (morning (ZT1) or afternoon (ZT6)). In contrast, LHY, which is often considered to act redundantly with CCA1, shows reduced transcript abundance under heat stress, suggesting that in response to specific environmental stimuli, they might have distinct functions [50] (Figure 2).

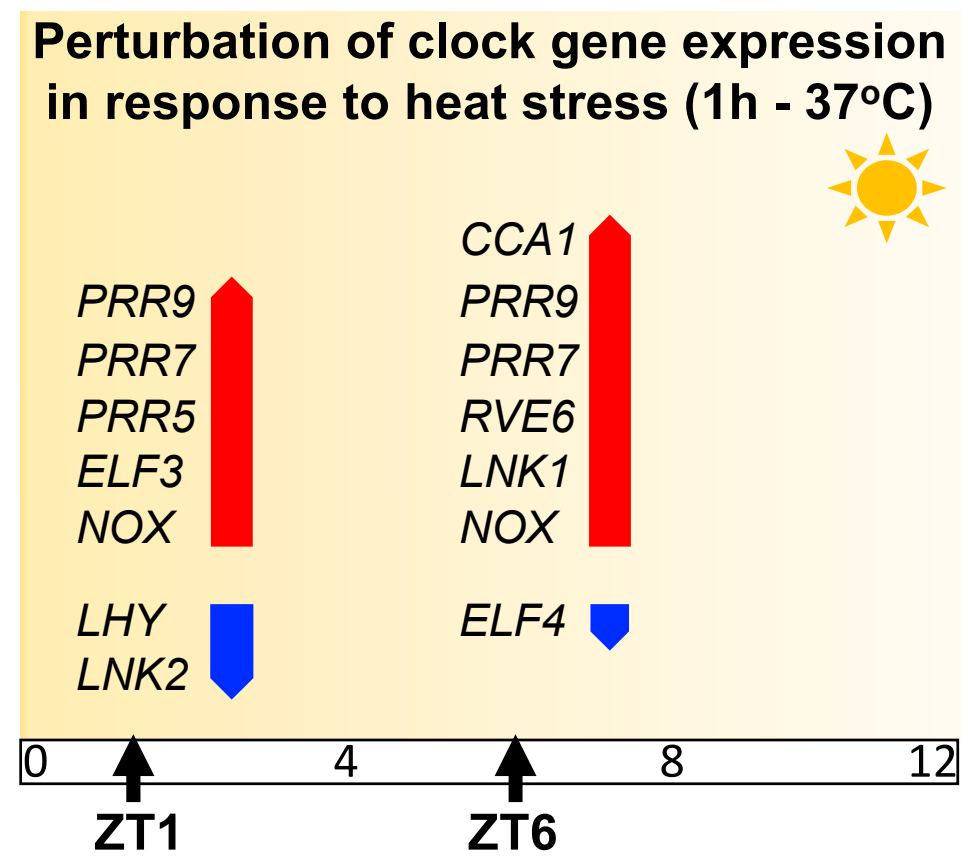

Figure 2. Impact of heat stress $\left(37^{\circ} \mathrm{C}\right)$ on transcript abundance of Arabidopsis clock components at two different times of the day (morning (ZT1) or afternoon (ZT6)). Upregulation (red arrow) and downregulation (blue arrow) are based on $\log 2$ fold change values obtained from RNA-seq analysis [50]. Only genes with statistically significant $($ FDR $<0.05)$ differences are represented.

Outside of Arabidopsis, clock genes are found across angiosperm genomes [60]. For the most part, the rhythmic time-of-day expression of clock and clock-controlled genes in crop species appears to be conserved [61-64]. For example, in monocots, such as rice and maize, the circadian phase of the core clock genes, CCA1 and TOC1, display similar time-of-day expression and flowering phenotypes, as observed in Arabidopsis [65-67]. Based on the available expression data in Genevestigator for crops, the transcript abundance of clock components appears to be impacted by heat stress to varying degrees [68]. Furthermore, in soybean, the perturbation of primary clock components in response to heat stress alters normal clock function [69]. Although global studies on the clock control of heat stress-responsive genes 
in many crops are not available, genes responsive to other abiotic stress show rhythmic expression in barley and soybean, suggesting that temperature stress-responsive genes might also be regulated by the clock in these species, and thus in crops in general [70,71]. In crassulacean acid metabolism (CAM) plants, which are known to be able to tolerate high temperatures and arid habitats, the clock also appears to be driven by a multigene oscillator [72-74]. In M. crystallinum, the adjustment of the timing of peak expression for some clock genes in response to a temperature pulse during the night might occur [72,75]. Furthermore, in pineapple, the promoters of CAM photosynthesis genes are enriched for cis-elements bound by clock genes [76]. However, the expression of Opuntia ficus-indica (cactus) clock genes OfiCCA1 and OfiPRR9 oscillate with a $12 \mathrm{~h}$ periodicity, unlike Arabidopsis, suggesting that the circadian clock in some CAM plants may be different from C3 and C4 plants [77]. Whether heat stress impacts the expression of clock and clock-controlled genes in a time-dependent context in CAM and C4 plants remains to be determined.

\section{Time-of-Day Regulation of Heat Shock Transcription Factors in Plants}

Downstream of the clock network, the expression of multiple genes is clock-regulated, in order to provide the optimal response to stress depending on the time of day. In plants, exposure to elevated temperatures activates the heat shock response (HSR) pathway and primarily triggers the synthesis of heat shock proteins (HSPs) [78-80]. The induction of HSP biosynthesis is, however, regulated by heat shock TFs (HSFs) [80,81]. Arabidopsis contains 21 HSFs, and interestingly, the transcript abundance of 17 of these HSFs show rhythmic expression [29]. Five HSFs cycle under free-running (constant) conditions, whereas 16 HSFs show rhythmic expression under photocycles or thermocycles [29]. Together, HSFs are expressed throughout the day (morning, afternoon, and evening), with at least one HSF showing timing of peak expression (phase) every 4 h (Figure 3) [29,81].

A

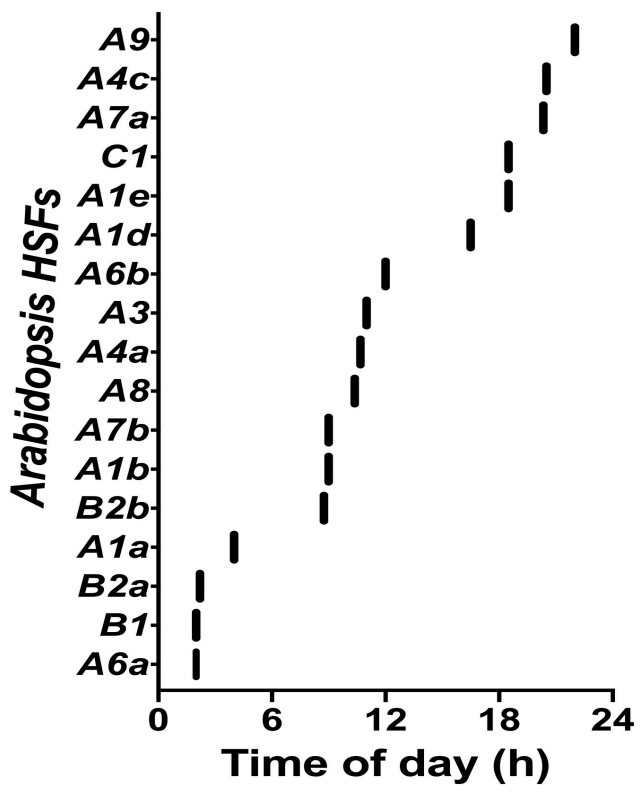

B

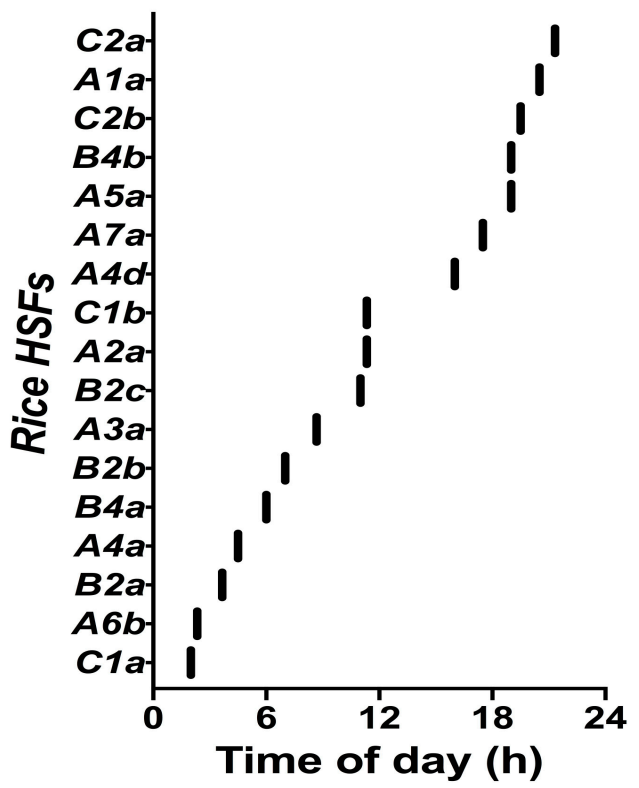

Figure 3. Timing of peak expression (phase) for plant heat shock transcription factors (HSFs) in (A) Arabidopsis (AtHSFs) and (B) rice (OsHSFs). The phase data was obtained from DIURNAL, and the average phase was calculated across all conditions available in DIURNAL for each plant species [29].

Although not all HSFs respond to heat stress, this TF family plays a role in other abiotic stress responses [50,59,81-83]. The observation that they are available at almost all time points during the day supports an important functional role of HSFs in the plant response to external stress signals, which is most likely mediated by the clock. HSFA1e, $A 3, A 4 a, A 6 b, A 8, B 2 a I$, and $C 1$ are direct targets 
of clock genes based on chromatin immunoprecipitation followed by deep sequencing (ChIP-seq); however, experimental evidence to link the biological significance of these interactions needs to be further examined [84-88]. Interestingly, one of the HSFS (HSFB2b) has been shown to play a role in the clock's ability to buffer against certain temperature changes, suggesting a feedback regulatory relationship between the time, temperature, and HSFs [89]. This interaction between the clock, heat stress and HSFs can be discerned from RNA-seq datasets that reveal how the time of day regulates HSFs' induction in response to heat stress. In Arabidopsis, HSFA2 and HSFA7 $b$ are induced by heat stress in the morning (ZT1) and afternoon (ZT6), respectively, and the induction is higher in the afternoon [50]. In contrast, HSFA3 transcript abundance accumulates to higher levels in the afternoon relative to the morning $[43,50]$. HSFB1, HSFB2 $a$, and HSFB2 $b$ are all heat-induced with higher transcript abundance in the afternoon, whereas HSFC1 gene expression is repressed by heat regardless of time of day $[50,90]$.

In rice, of the $25 \mathrm{HSFs}$ that are present, 17 show rhythmic expression under diurnal conditions (light or temperature); interestingly, 11 out of those 17 are induced by heat stress (Figure 3) [29,91]. For the most part, the time of peak expression of cycling HSFs is not consistently conserved between Arabidopsis and rice. However, a few HSFs belonging to either the HSF A, B, or C clade appear to show highest expression at similar phases of the day for both species. For example, AtHSFA7a, AtHSFC1, OsHSFA7a, OsHSFC2a, and OsHSFC2b show peak expression in the early morning (ZT18-24); AtHSFB2a and OsHSFB2a peak in the morning (ZT0-ZT4); AtHSFB2b and OsHSFB2 $b$ peak in the afternoon to early evening (ZT6-ZT8); and AtHSFA3 and OsHSFA3a peak in the evening (ZT8-ZT12) (Figure 3). Furthermore, other HSFs are also expressed at different times of the day. Taken together, HSFs in Arabidopsis and rice are expressed throughout the day, but each individual heat-responsive HSF cycles with a unique phase of peak expression during the $24 \mathrm{~h}$ period, suggesting temporal partitioning of gene expression in response to temperature stress (Figure 3). Interestingly, in pineapple, five HSFs are regulated by the circadian clock and show peak expression in the morning [92]. This suggests that even CAM plants that might be more tolerant to extreme temperature environments, and that heat responsive regulators are controlled in a time-of-day-dependent thermotolerance mechanism.

While HSFA1s are the master transcriptional regulators of the early heat stress response in plants, the clock genes REVEILLE4 (RVE4) and RVE8 might play key roles in an HSF-independent pathway during the first wave of the heat stress response [59]. The role of RVE 8 in plant thermotolerance is gated by the circadian clock, with a specific regulation around ZT6 to ZT7 [59]. However, the highest thermotolerance occurs at ZT15 to ZT16, suggesting the activation of additional clock-controlled regulators at this particular time of day [59].

Since plants are subjected to varying temperatures throughout the day, with the highest temperature experienced around or after noon, their physiological response to temperature also differs throughout the 24-hour day. Hence, plants need to have time-of-day-dependent temperature response, which at the cellular level requires gene regulation by multiple TF families.

Thus, further insights into the influence of the time of day on heat stress events for cycling transcriptional networks will help to decipher the dynamic nature of the heat stress response throughout the day.

\section{Time of Day and other Clock-Regulated Heat Responsive Transcription Factor Families}

In response to abiotic stresses, several TFs act as master regulators of the responsive pathways. TFs exhibiting circadian oscillations and directly targeted by clock genes could have a specific role during the day in response to a particular stress. From the list of differentially expressed genes identified in two recent heat responsive transcriptomes, $\sim 12 \%$ and $\sim 9 \%$ of the upregulated and downregulated transcripts, respectively, correspond to TFs [50,59,93] (Table S1). Of these, 50\% (308 TFs) exhibit circadian oscillations in constant light conditions, and are members of 59 different families, highlighting the diversity of the transcriptional regulators controlled by the circadian clock and involved in the heat stress response [29]. An in-house enrichment analysis highlighted 17 families that are over-represented in at least one heat responsive transcriptome dataset, compared to all Arabidopsis TFs, which suggests 
that these TF families might be important in context-dependent regulatory hubs (Table S1). The GRAS and MYB TF families are two of the most over-represented families in cycling transcripts that are downregulated in response to heat, especially during the early response (Table S1). These two families participate in many aspects of plant growth and development [94,95]. Thus, transcriptional regulation of these family members under heat reflects the adjustment of developmental processes in response to this stress. For example, MYB59 expression peaks in the afternoon, and its transcript abundance has been shown to be reduced within $10 \mathrm{~min}$ following exposure to heat, but only between ZT3-ZT6 [59]. Similarly, the GRAS member SCL13 is upregulated after $1 \mathrm{~h}$ of heat stress exposure but only in the early morning, when its expression starts to increase [50,96,97]. Interestingly, overexpression of OsMYB55 results in improved plant growth and performance under high temperature in both rice and maize [98,99]. The Arabidopsis MYB59 and SCL13 TFs not only oscillate in constant light conditions, but are also direct targets of clock genes, suggesting that they might be key proteins mediating crosstalk between the clock and the plant response to elevated temperature $[84,85,87,100]$.

In response to abiotic stresses, the large $A P 2-E R E P B$ family plays an important role, and is well represented in heat-inducible TFs that exhibit circadian oscillations (Table S1). DREB2A is expressed in the evening, and functions as a key regulator of drought tolerance [101,102]. DREB2A activates the expression of HSFA3, which contributes to the establishment of thermotolerance [101,103]. Upregulation of $D R E B 2 A$ is detected after $15 \mathrm{~min}$ of heat exposure, followed by the upregulation of HSFA3 after $30 \mathrm{~min}$, and high transcription levels for both genes are maintained after $1 \mathrm{~h}$, regardless of time of day [50,59]. A similar response has been observed for $D R E B 2 B$, and overexpression of the rice OsDREB2A and OsDREB2B showed improved plant tolerance to drought, suggesting a conservation of the regulatory mechanisms across plant species [104,105]. Other DREB TFs, designated CBFs, have been shown to be regulated by cold, high ambient temperatures, and heat stress, implicating them as important regulators linking the clock to temperature stress response mechanisms $[43,44,50,58]$.

Cycling bZIPs are also well-represented in heat responsive TFs (Supplementary Table S1), and crops over-expressing bZIP proteins have been reported to better tolerate abiotic stresses [106-108]. In addition, high ambient temperatures revealed the enrichment of a $b Z I P$ TF binding element in night-responsive genes [43]. The morning-expressed $A B F 3$ is upregulated in response to heat stress at ZT6 [50]. ABF3 is a master regulator of $A B A$-regulated genes, and its overexpression improved plant tolerance to drought stress in rice [109]. Because drought often occurs in warm conditions, many TFs regulated by heat also act in drought responsive pathways. Thus, modulation of the expression of many of these TFs might result from the coordination of multiple pathways commonly activated in abiotic stress responses (e.g., temperature, drought, hormone and ROS signaling, calcium-mediated stress signaling, redox homeostasis, etc.).

Although we have discussed the major TF families above, other oscillating TFs play important roles in thermotolerance, and are not necessarily over-represented in the heat responsive transcriptomes assayed in this review. For example, several members of the $b H L H$ family, such as PHYTOCHROME-INTERACTING FACTORS (PIFS), have been identified in heat-induced transcriptomes. PIF4 has been shown to be upregulated in response to hot and warm temperatures in the early morning and at night, respectively [43,50]. Moreover, transcriptomic and ChIP-seq analyses also revealed PIF1 and PIF5 as cycling TFs, directly bound by clock genes and upregulated in response to warm temperature $[20,29,43,84,86,88,110]$. MBF1C is a central regulator of plant thermotolerance [111]. Under heat, its transcript abundance increases after $5 \mathrm{~min}$, and MBF1c regulates the expression of $D R E B 2 A$ and two HSFBs, demonstrating its role in the interplay between the clock and the HSR pathway $[59,112]$. Together, these collective connections highlight the multi-level, time-of-day TF network underlying heat stress responses in plants.

\section{Integrated Time of day and Heat Stress Transcriptional Networks}

From transcriptomic datasets generated in Blair et al. [50], Grinevich et al. [43], and Li et al. [59], 169 TFs responding to hot or warm temperatures cycle under constant light and are direct targets of the 
clock $[20,29,84-88,100,110]$. These TFs are members of 19 TF families over-represented in differentially expressed genes (Figure 4). CCA1 and LHY target most of the represented families, highlighting their importance in regulating heat responsive TFs (Figure 4). Because most of the ChIP-seq data were not obtained at high temperatures, it would be interesting to study the influence of heat stress on the target selection of output genes. Nonetheless, using such network representation allows us to identify the specificity of clock genes for a particular heat-responsive TF family, and to visualize TF families that are targeted by one or multiple clock genes. Interestingly, the PRR family is the only represented family that is targeted by all the analyzed clock genes (Figure 4). All five members of this family were upregulated in response to heat (PRR1, PRR3, PRR5, PRR7, and PRR9), and are targets of at least one clock gene. (Figure 4 ).

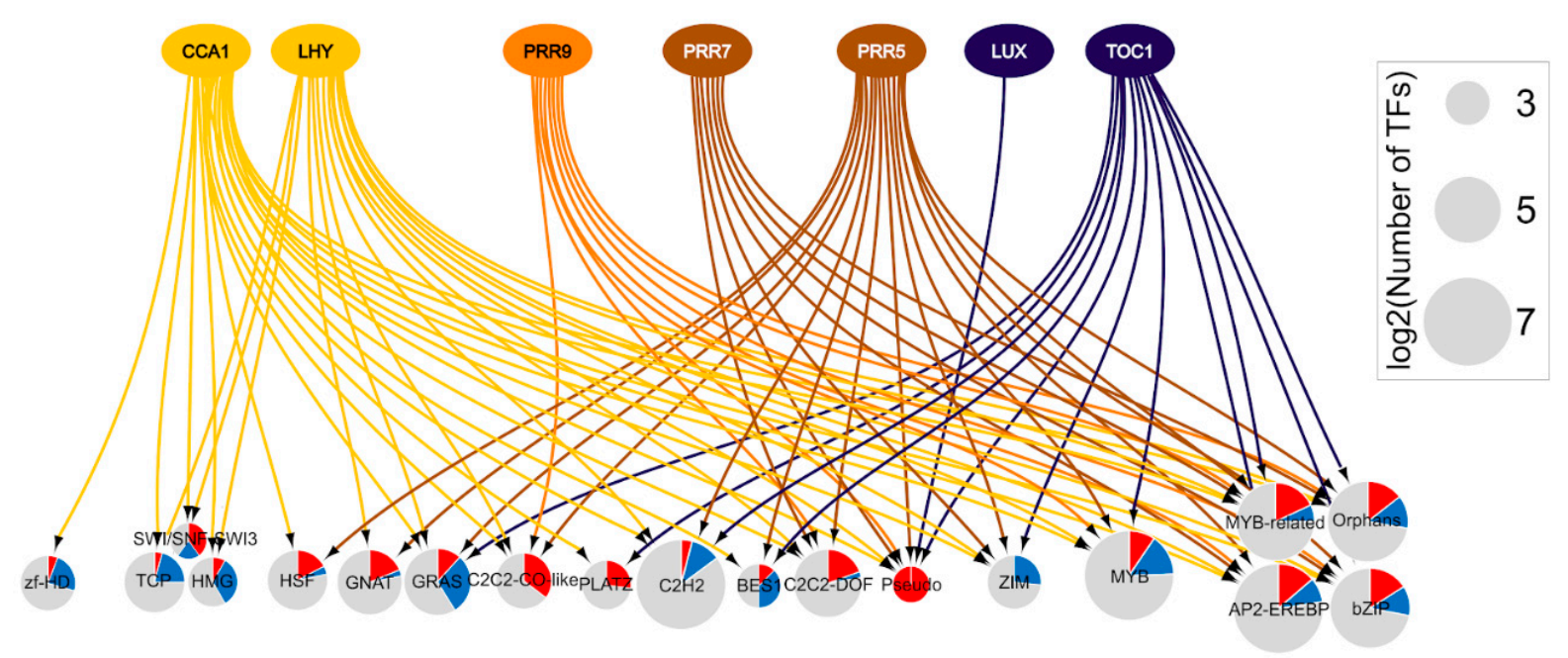

Figure 4. Transcriptional network of heat-responsive transcription factor families that are also cycling. The represented TF families are significantly over-represented in these high-temperature-responsive transcriptome datasets $[43,50,59]$ (Supplementary Table S1), and include direct targets of CCA1, LHY, PRR7, PRR9, PRR5, LUX, and TOC1, based on ChIP-seq datasets [20,84-88,100,110]. The arrows in the network represent an interaction between the TF and its target. These connections indicate that at least one member of the TF family is a target of clock genes; however, not all members of the TF family are responding to heat. The node size for TF families reflects the size of the family, with the Log2-transformed total number of TFs. The colors in pie charts represent the proportion of TFs differentially expressed in response to heat. Blue pie: downregulated; red pie: upregulated; grey pie: not significant.

To identify the regulators of plant thermo-responses, comparing heat-responsive transcriptomes is often complicated by the use of different experimental conditions, materials (temperature, light intensity, plant age, etc.), and data analysis methods (pipelines used for RNA-Seq data analysis, statistical models, and thresholds used to identify differentially expressed genes, etc.). However, despite the disparities between the methods, the differences of differentially expressed TFs between studies also demonstrate the specific role of the heat stress-responsive TFs. This specificity probably reflects the influence of the time of day, the duration of exposure, and the temperature applied to the plants. This also emphasizes the importance of combining data to obtain the most representative vision of the regulatory mechanisms involved in the plant response to stresses in a clock-dependent context.

\section{Future Perspective}

Major advances in the development and improvement of food crops is absolutely essential for feeding and nourishing the increasing world population [113]. In order to understand how plants respond to extreme environmental stress, comprehensive knowledge of the genes, regulatory pathways, and underlying mechanisms are critical $[1,3,5,114]$. Emerging studies reinforce that plant growth and 
survival under heat stress is directly dependent on the time of day, and that the clock integrates these signals to modulate timed responses that likely contribute to enhancing plant fitness. In this review, we mainly focus on components of the circadian oscillator and downstream TFs that respond to heat stress. Future gene-editing techniques to control and fine-tune the response to temperature stress by modifying promoters of heat-responsive and clock-controlled genes will be invaluable. In addition, a mechanistic understanding of how heat stress impacts all levels of gene regulation and how genes interact to promote a singular response to heat stress vs. a general stress response is needed. Modeling and network analyses that integrate multiple levels of gene regulatory networks will no doubt shed light on how key biological events will be perceived and processed in plants in future environmental changes. Integrated knowledge will enable the generation of predictive models for outcomes of plant tolerance in the context of climate change.

Supplementary Materials: The following are available online at http://www.mdpi.com/2073-4425/11/2/156/s1, Table S1. Enrichment of rhythmic transcription factor families in heat responsive transcriptomes.

Funding: This research received no external funding.

Acknowledgments: The authors wish to thank members of the Nagel lab for useful comments on the review. We sincerely apologize to our colleagues whose work was not included here due to space constraints.

Conflicts of Interest: The authors declare no conflict of interest.

\section{References}

1. Bailey-Serres, J.; Parker, J.E.; Ainsworth, E.A.; Oldroyd, G.E.D.; Schroeder, J.I. Genetic strategies for improving crop yields. Nature 2019, 575, 109-118. [CrossRef] [PubMed]

2. Zhao, C.; Liu, B.; Piao, S.; Wang, X.; Lobell, D.B.; Huang, Y.; Huang, M.; Yao, Y.; Bassu, S.; Ciais, P.; et al. Temperature increase reduces global yields of major crops in four independent estimates. Proc. Natl. Acad. Sci. USA 2017, 114, 9326-9331. [CrossRef] [PubMed]

3. Bita, C.E.; Gerats, T. Plant tolerance to high temperature in a changing environment: scientific fundamentals and production of heat stress-tolerant crops. Front. Plant Sci. 2013, 4, 273. [CrossRef] [PubMed]

4. Hasanuzzaman, M.; Nahar, K.; Alam, M.M.; Roychowdhury, R.; Fujita, M. Physiological, biochemical, and molecular mechanisms of heat stress tolerance in plants. Int. J. Mol. Sci. 2013, 14, 9643-9684. [CrossRef] [PubMed]

5. Lamaoui, M.; Jemo, M.; Datla, R.; Bekkaoui, F. Heat and Drought Stresses in Crops and Approaches for Their Mitigation. Front. Chem. 2018, 6, 26. [CrossRef]

6. Penfield, S. Temperature perception and signal transduction in plants. New Phytol. 2008, 179, 615-628. [CrossRef]

7. Nohales, M.A.; Kay, S.A. Molecular mechanisms at the core of the plant circadian oscillator. Nat. Struct. Mol. Biol. 2016, 23, 1061-1069. [CrossRef]

8. Harmer, S.L. The circadian system in higher plants. Annu. Rev. Plant Biol. 2009, 60, 357-377. [CrossRef]

9. Greenham, K.; McClung, C.R. Integrating circadian dynamics with physiological processes in plants. Nat. Rev. Genet. 2015, 16, 598-610. [CrossRef]

10. Dodd, A.N.; Salathia, N.; Hall, A.; Kévei, E.; Tóth, R.; Nagy, F.; Hibberd, J.M.; Millar, A.J.; Webb, A.A.R. Plant circadian clocks increase photosynthesis, growth, survival, and competitive advantage. Science 2005, 309, 630-633. [CrossRef]

11. McClung, C.R.; Davis, S.J. Ambient thermometers in plants: from physiological outputs towards mechanisms of thermal sensing. Curr. Biol. CB 2010, 20, R1086-R1092. [CrossRef] [PubMed]

12. Gil, K.-E.; Park, C.-M. Thermal adaptation and plasticity of the plant circadian clock. New Phytol. 2019, 221, 1215-1229. [CrossRef] [PubMed]

13. Espinoza, C.; Degenkolbe, T.; Caldana, C.; Zuther, E.; Leisse, A.; Willmitzer, L.; Hincha, D.K.; Hannah, M.A. Interaction with Diurnal and Circadian Regulation Results in Dynamic Metabolic and Transcriptional Changes during Cold Acclimation in Arabidopsis. PLoS ONE 2010, 5, e14101. [CrossRef] [PubMed]

14. Rienth, M.; Torregrosa, L.; Luchaire, N.; Chatbanyong, R.; Lecourieux, D.; Kelly, M.T.; Romieu, C. Day and night heat stress trigger different transcriptomic responses in green and ripening grapevine (vitis vinifera) fruit. BMC Plant Biol. 2014, 14, 108. [CrossRef] [PubMed] 
15. Shi, W.; Yin, X.; Struik, P.C.; Solis, C.; Xie, F.; Schmidt, R.C.; Huang, M.; Zou, Y.; Ye, C.; Jagadish, S.V.K. High day- and night-time temperatures affect grain growth dynamics in contrasting rice genotypes. J. Exp. Bot. 2017, 68, 5233-5245. [CrossRef] [PubMed]

16. Nagel, D.H.; Kay, S.A. Complexity in the wiring and regulation of plant circadian networks. Curr. Biol. $C B$ 2012, 22, R648-R657. [CrossRef] [PubMed]

17. Hsu, P.Y.; Harmer, S.L. Wheels within wheels: the plant circadian system. Trends Plant Sci. 2014, 19, $240-249$. [CrossRef]

18. Alabadí, D.; Oyama, T.; Yanovsky, M.J.; Harmon, F.G.; Más, P.; Kay, S.A. Reciprocal regulation between TOC1 and LHY/CCA1 within the Arabidopsis circadian clock. Science 2001, 293, 880-883. [CrossRef]

19. Sanchez, S.E.; Kay, S.A. The Plant Circadian Clock: From a Simple Timekeeper to a Complex Developmental Manager. Cold Spring Harb. Perspect. Biol. 2016, 8. [CrossRef]

20. Huang, W.; Pérez-García, P.; Pokhilko, A.; Millar, A.J.; Antoshechkin, I.; Riechmann, J.L.; Mas, P. Mapping the core of the Arabidopsis circadian clock defines the network structure of the oscillator. Science 2012, 336, 75-79. [CrossRef]

21. Pokhilko, A.; Fernández, A.P.; Edwards, K.D.; Southern, M.M.; Halliday, K.J.; Millar, A.J. The clock gene circuit in Arabidopsis includes a repressilator with additional feedback loops. Mol. Syst. Biol. 2012, 8, 574. [CrossRef] [PubMed]

22. Alabadí, D.; Yanovsky, M.J.; Más, P.; Harmer, S.L.; Kay, S.A. Critical role for CCA1 and LHY in maintaining circadian rhythmicity in Arabidopsis. Curr. Biol. CB 2002, 12, 757-761. [CrossRef]

23. Pruneda-Paz, J.L.; Breton, G.; Para, A.; Kay, S.A. A functional genomics approach reveals CHE as a component of the Arabidopsis circadian clock. Science 2009, 323, 1481-1485. [CrossRef] [PubMed]

24. Rawat, R.; Takahashi, N.; Hsu, P.Y.; Jones, M.A.; Schwartz, J.; Salemi, M.R.; Phinney, B.S.; Harmer, S.L. REVEILLE8 and PSEUDO-REPONSE REGULATOR5 form a negative feedback loop within the Arabidopsis circadian clock. PLoS Genet. 2011, 7, e1001350. [CrossRef]

25. Nakamichi, N.; Kiba, T.; Henriques, R.; Mizuno, T.; Chua, N.-H.; Sakakibara, H. PSEUDO-RESPONSE REGULATORS 9, 7, and 5 Are Transcriptional Repressors in the Arabidopsis Circadian Clock. Plant Cell 2010, 22, 594-605. [CrossRef]

26. Huang, H.; Nusinow, D.A. Into the Evening: Complex Interactions in the Arabidopsis Circadian Clock. Trends Genet. 2016, 32, 674-686. [CrossRef]

27. Adams, S.; Manfield, I.; Stockley, P.; Carré, I.A. Revised Morning Loops of the Arabidopsis Circadian Clock Based on Analyses of Direct Regulatory Interactions. PLOS ONE 2015, 10, e0143943. [CrossRef]

28. Matsushika, A.; Makino, S.; Kojima, M.; Mizuno, T. Circadian waves of expression of the APRR1/TOC1 family of pseudo-response regulators in Arabidopsis thaliana: insight into the plant circadian clock. Plant Cell Physiol. 2000, 41, 1002-1012. [CrossRef]

29. Mockler, T.C.; Michael, T.P.; Priest, H.D.; Shen, R.; Sullivan, C.M.; Givan, S.A.; McEntee, C.; Kay, S.A.; Chory, J. The DIURNAL project: DIURNAL and circadian expression profiling, model-based pattern matching, and promoter analysis. Cold Spring Harb. Symp. Quant. Biol. 2007, 72, 353-363. [CrossRef]

30. Eckardt, N.A. Temperature Entrainment of the Arabidopsis Circadian Clock. Plant Cell 2005, 17, 645-647. [CrossRef]

31. Wang, Y.; Yuan, L.; Su, T.; Wang, Q.; Gao, Y.; Zhang, S.; Jia, Q.; Yu, G.; Fu, Y.; Cheng, Q.; et al. Light- and temperature-entrainable circadian clock in soybean development. Plant Cell Environ. 2019. [CrossRef]

32. Panter, P.E.; Muranaka, T.; Cuitun-Coronado, D.; Graham, C.A.; Yochikawa, A.; Kudoh, H.; Dodd, A.N. Circadian Regulation of the Plant Transcriptome Under Natural Conditions. Front. Genet. 2019, 10, 1239. [CrossRef]

33. Fankhauser, C.; Staiger, D. Photoreceptors in Arabidopsis thaliana: light perception, signal transduction and entrainment of the endogenous clock. Planta 2002, 216, 1-16. [CrossRef]

34. Gould, P.D.; Locke, J.C.W.; Larue, C.; Southern, M.M.; Davis, S.J.; Hanano, S.; Moyle, R.; Milich, R.; Putterill, J.; Millar, A.J.; et al. The molecular basis of temperature compensation in the Arabidopsis circadian clock. Plant Cell 2006, 18, 1177-1187. [CrossRef]

35. Avello, P.A.; Davis, S.J.; Ronald, J.; Pitchford, J.W. Heat the Clock: Entrainment and Compensation in Arabidopsis Circadian Rhythms. J. Circadian Rhythms 2019, 17, 5. [CrossRef]

36. Thines, B.; Harmon, F.G. Ambient temperature response establishes ELF3 as a required component of the core Arabidopsis circadian clock. Proc. Natl. Acad. Sci. USA 2010, 107, 3257-3262. [CrossRef] 
37. Salomé, P.A.; Weigel, D.; McClung, C.R. The role of the Arabidopsis morning loop components CCA1, LHY, PRR7, and PRR9 in temperature compensation. Plant Cell 2010, 22, 3650-3661. [CrossRef]

38. Legris, M.; Klose, C.; Burgie, E.S.; Rojas, C.C.R.; Neme, M.; Hiltbrunner, A.; Wigge, P.A.; Schäfer, E.; Vierstra, R.D.; Casal, J.J. Phytochrome B integrates light and temperature signals in Arabidopsis. Science 2016, 354, 897-900. [CrossRef]

39. Jung, J.-H.; Domijan, M.; Klose, C.; Biswas, S.; Ezer, D.; Gao, M.; Khattak, A.K.; Box, M.S.; Charoensawan, V.; Cortijo, S.; et al. Phytochromes function as thermosensors in Arabidopsis. Science 2016, 354, 886-889. [CrossRef]

40. Zhu, J.-Y.; Oh, E.; Wang, T.; Wang, Z.-Y. TOC1-PIF4 interaction mediates the circadian gating of thermoresponsive growth in Arabidopsis. Nat. Commun. 2016, 7, 13692. [CrossRef]

41. Filichkin, S.A.; Cumbie, J.S.; Dharmawadhana, J.P.; Jaiswal, P.; Chang, J.H.; Palusa, S.G.; Reddy, A.S.N.; Megraw, M.; Mockler, T.C. Environmental Stresses Modulate Abundance and Timing of Alternatively Spliced Circadian Transcripts in Arabidopsis. Mol. Plant 2014. [CrossRef] [PubMed]

42. Kangisser, S.; Yakir, E.; Green, R.M. Proteasomal regulation of CIRCADIAN CLOCK ASSOCIATED 1 (CCA1) stability is part of the complex control of CCA1. Plant Signal. Behav. 2013, 8, e23206. [CrossRef] [PubMed]

43. Grinevich, D.O.; Desai, J.S.; Stroup, K.P.; Duan, J.; Slabaugh, E.; Doherty, C.J. Novel transcriptional responses to heat revealed by turning up the heat at night. Plant Mol. Biol. 2019, 101, 1-19. [CrossRef] [PubMed]

44. Fowler, S.G.; Cook, D.; Thomashow, M.F. Low temperature induction of Arabidopsis CBF1, 2, and 3 is gated by the circadian clock. Plant Physiol. 2005, 137, 961-968. [CrossRef] [PubMed]

45. Espinoza, C.; Bieniawska, Z.; Hincha, D.K.; Hannah, M.A. Interactions between the circadian clock and cold-response in Arabidopsis. Plant Signal. Behav. 2008, 3, 593-594. [CrossRef] [PubMed]

46. Bieniawska, Z.; Espinoza, C.; Schlereth, A.; Sulpice, R.; Hincha, D.K.; Hannah, M.A. Disruption of the Arabidopsis circadian clock is responsible for extensive variation in the cold-responsive transcriptome. Plant Physiol. 2008, 147, 263-279. [CrossRef]

47. Grundy, J.; Stoker, C.; Carré, I.A. Circadian regulation of abiotic stress tolerance in plants. Front. Plant Sci. 2015, 6, 648. [CrossRef]

48. Seo, P.J.; Mas, P. STRESSing the role of the plant circadian clock. Trends Plant Sci. 2015, 20, 230-237. [CrossRef]

49. Davis, A.M.; Ronald, J.; Ma, Z.; Wilkinson, A.J.; Philippou, K.; Shindo, T.; Queitsch, C.; Davis, S.J. HSP90 Contributes to Entrainment of the Arabidopsis Circadian Clock via the Morning Loop. Genetics 2018, 210, 1383-1390. [CrossRef]

50. Blair, E.J.; Bonnot, T.; Hummel, M.; Hay, E.; Marzolino, J.M.; Quijada, I.A.; Nagel, D.H. Contribution of time of day and the circadian clock to the heat stress responsive transcriptome in Arabidopsis. Sci. Rep. 2019, 9. [CrossRef]

51. Gil, K.-E.; Kim, W.-Y.; Lee, H.-J.; Faisal, M.; Saquib, Q.; Alatar, A.A.; Park, C.-M. ZEITLUPE Contributes to a Thermoresponsive Protein Quality Control System in Arabidopsis. Plant Cell 2017, 29, 2882-2894. [CrossRef] [PubMed]

52. Filichkin, S.A.; Mockler, T.C. Unproductive alternative splicing and nonsense mRNAs: A widespread phenomenon among plant circadian clock genes. Biol. Direct 2012, 7, 20. [CrossRef] [PubMed]

53. Covington, M.F.; Maloof, J.N.; Straume, M.; Kay, S.A.; Harmer, S.L. Global transcriptome analysis reveals circadian regulation of key pathways in plant growth and development. Genome Biol. 2008, 9, R130. [CrossRef] [PubMed]

54. Nakamichi, N.; Kusano, M.; Fukushima, A.; Kita, M.; Ito, S.; Yamashino, T.; Saito, K.; Sakakibara, H.; Mizuno, T. Transcript profiling of an Arabidopsis PSEUDO RESPONSE REGULATOR arrhythmic triple mutant reveals a role for the circadian clock in cold stress response. Plant Cell Physiol. 2009, 50, 447-462. [CrossRef]

55. Keily, J.; MacGregor, D.R.; Smith, R.W.; Millar, A.J.; Halliday, K.J.; Penfield, S. Model selection reveals control of cold signalling by evening-phased components of the plant circadian clock. Plant J. 2013, 76, 247-257. [CrossRef]

56. Cao, S.; Ye, M.; Jiang, S. Involvement of GIGANTEA gene in the regulation of the cold stress response in Arabidopsis. Plant Cell Rep. 2005, 24, 683-690. [CrossRef]

57. Chow, B.Y.; Sanchez, S.E.; Breton, G.; Pruneda-Paz, J.L.; Krogan, N.T.; Kay, S.A. Transcriptional regulation of LUX by CBF1 mediates cold input to the circadian clock in Arabidopsis. Curr. Biol. CB 2014, 24, 1518-1524. [CrossRef] 
58. Dong, M.A.; Farré, E.M.; Thomashow, M.F. Circadian clock-associated 1 and late elongated hypocotyl regulate expression of the C-repeat binding factor (CBF) pathway in Arabidopsis. Proc. Natl. Acad. Sci. USA 2011, 108, 7241-7246. [CrossRef]

59. Li, B.; Gao, Z.; Liu, X.; Sun, D.; Tang, W. Transcriptional Profiling Reveals a Time-of-Day-Specific Role of REVEILLE 4/8 in Regulating the First Wave of Heat Shock-Induced Gene Expression in Arabidopsis. Plant Cell 2019, 31, 2353-2369. [CrossRef]

60. McClung, C.R. Beyond Arabidopsis: The circadian clock in non-model plant species. Semin. Cell Dev. Biol. 2013, 24, 430-436. [CrossRef]

61. Filichkin, S.A.; Breton, G.; Priest, H.D.; Dharmawardhana, P.; Jaiswal, P.; Fox, S.E.; Michael, T.P.; Chory, J.; Kay, S.A.; Mockler, T.C. Global profiling of rice and poplar transcriptomes highlights key conserved circadian-controlled pathways and cis-regulatory modules. PLoS ONE 2011, 6, e16907. [CrossRef]

62. Hudson, K.A. The Circadian Clock-controlled Transcriptome of Developing Soybean Seeds. Plant Genome J. 2010, 3, 3. [CrossRef]

63. Khan, S.; Rowe, S.C.; Harmon, F.G. Coordination of the maize transcriptome by a conserved circadian clock. BMC Plant Biol. 2010, 10, 126. [CrossRef] [PubMed]

64. Calixto, C.P.G.; Waugh, R.; Brown, J.W.S. Evolutionary Relationships Among Barley and Arabidopsis Core Circadian Clock and Clock-Associated Genes. J. Mol. Evol. 2015, 80, 108-119. [CrossRef] [PubMed]

65. Murakami, M.; Tago, Y.; Yamashino, T.; Mizuno, T. Comparative Overviews of Clock-Associated Genes of Arabidopsis thaliana and Oryza sativa. Plant Cell Physiol. 2007, 48, 110-121. [CrossRef] [PubMed]

66. Wang, X.; Wu, L.; Zhang, S.; Wu, L.; Ku, L.; Wei, X.; Xie, L.; Chen, Y. Robust expression and association of ZmCCA1 with circadian rhythms in maize. Plant Cell Rep. 2011, 30, 1261-1272. [CrossRef] [PubMed]

67. Ko, D.K.; Rohozinski, D.; Song, Q.; Taylor, S.H.; Juenger, T.E.; Harmon, F.G.; Chen, Z.J. Temporal Shift of Circadian-Mediated Gene Expression and Carbon Fixation Contributes to Biomass Heterosis in Maize Hybrids. PLoS Genet. 2016, 12, e1006197. [CrossRef]

68. Hruz, T.; Laule, O.; Szabo, G.; Wessendorp, F.; Bleuler, S.; Oertle, L.; Widmayer, P.; Gruissem, W.; Zimmermann, P. Genevestigator v3: a reference expression database for the meta-analysis of transcriptomes. Adv. Bioinforma. 2008, 2008, 420747. [CrossRef]

69. Li, M.; Cao, L.; Mwimba, M.; Zhou, Y.; Li, L.; Zhou, M.; Schnable, P.S.; O’Rourke, J.A.; Dong, X.; Wang, W. Comprehensive mapping of abiotic stress inputs into the soybean circadian clock. Proc. Natl. Acad. Sci. USA 2019, 116, 23840-23849. [CrossRef]

70. Marcolino-Gomes, J.; Rodrigues, F.A.; Fuganti-Pagliarini, R.; Bendix, C.; Nakayama, T.J.; Celaya, B.; Molinari, H.B.C.; de Oliveira, M.C.N.; Harmon, F.G.; Nepomuceno, A. Diurnal Oscillations of Soybean Circadian Clock and Drought Responsive Genes. PLoS ONE 2014, 9, e86402. [CrossRef]

71. Habte, E.; Müller, L.M.; Shtaya, M.; Davis, S.J.; Von Korff, M. Osmotic stress at the barley root affects expression of circadian clock genes in the shoot: Osmotic stress changes the barley circadian clock. Plant Cell Environ. 2014, 37, 1321-1337. [CrossRef] [PubMed]

72. Borland, A.M.; Griffiths, H.; Hartwell, J.; Smith, J.A.C. Exploiting the potential of plants with crassulacean acid metabolism for bioenergy production on marginal lands. J. Exp. Bot. 2009, 60, 2879-2896. [CrossRef] [PubMed]

73. Boxall, S.F.; Foster, J.M.; Bohnert, H.J.; Cushman, J.C.; Nimmo, H.G.; Hartwell, J. Conservation and Divergence of Circadian Clock Operation in a Stress-Inducible Crassulacean Acid Metabolism Species Reveals Clock Compensation against Stress. Plant Physiol. 2005, 137, 969-982. [CrossRef] [PubMed]

74. Endogenous Plant Rhythms; Hall, A.J.W.; McWatterss, H. (Eds.) Blackwell Publishing Ltd: Oxford, UK, 2006; ISBN 978-0-470-98852-7.

75. Hartwell, J. The co-ordination of central plant metabolism by the circadian clock. Biochem. Soc. Trans. 2005, 33, 945. [CrossRef]

76. Ming, R.; VanBuren, R.; Wai, C.M.; Tang, H.; Schatz, M.C.; Bowers, J.E.; Lyons, E.; Wang, M.-L.; Chen, J.; Biggers, E.; et al. The pineapple genome and the evolution of CAM photosynthesis. Nat. Genet. 2015, 47, 1435-1442. [CrossRef]

77. Mallona, I.; Egea-Cortines, M.; Weiss, J. Conserved and Divergent Rhythms of Crassulacean Acid Metabolism-Related and Core Clock Gene Expression in the Cactus Opuntia ficus-indica. Plant Physiol. 2011, 156, 1978-1989. [CrossRef]

78. Lindquist, S. The heat-shock response. Annu. Rev. Biochem. 1986, 55, 1151-1191. [CrossRef] 
79. Lindquist, S.; Craig, E.A. The heat-shock proteins. Annu. Rev. Genet. 1988, 22, 631-677. [CrossRef]

80. Morimoto, R.I. Regulation of the heat shock transcriptional response: Cross talk between a family of heat shock factors, molecular chaperones, and negative regulators. Genes Dev. 1998, 12, 3788-3796. [CrossRef]

81. Scharf, K.-D.; Berberich, T.; Ebersberger, I.; Nover, L. The plant heat stress transcription factor (Hsf) family: structure, function and evolution. Biochim. Biophys. Acta 2012, 1819, 104-119. [CrossRef]

82. Albihlal, W.S.; Obomighie, I.; Blein, T.; Persad, R.; Chernukhin, I.; Crespi, M.; Bechtold, U.; Mullineaux, P.M. Arabidopsis HEAT SHOCK TRANSCRIPTION FACTORA1b regulates multiple developmental genes under benign and stress conditions. J. Exp. Bot. 2018, 69, 2847-2862. [CrossRef] [PubMed]

83. Liu, H.-C.; Liao, H.-T.; Charng, Y.-Y. The role of class A1 heat shock factors (HSFA1s) in response to heat and other stresses in Arabidopsis. Plant Cell Environ. 2011, 34, 738-751. [CrossRef] [PubMed]

84. Nagel, D.H.; Doherty, C.J.; Pruneda-Paz, J.L.; Schmitz, R.J.; Ecker, J.R.; Kay, S.A. Genome-wide identification of CCA1 targets uncovers an expanded clock network in Arabidopsis. Proc. Natl. Acad. Sci. USA 2015, 112, E4802-E4810. [CrossRef] [PubMed]

85. Kamioka, M.; Takao, S.; Suzuki, T.; Taki, K.; Higashiyama, T.; Kinoshita, T.; Nakamichi, N. Direct Repression of Evening Genes by CIRCADIAN CLOCK-ASSOCIATED1 in the Arabidopsis Circadian Clock. Plant Cell 2016, 28, 696-711. [CrossRef] [PubMed]

86. Nakamichi, N.; Kiba, T.; Kamioka, M.; Suzuki, T.; Yamashino, T.; Higashiyama, T.; Sakakibara, H.; Mizuno, T. Transcriptional repressor PRR5 directly regulates clock-output pathways. Proc. Natl. Acad. Sci. USA 2012, 109, 17123-17128. [CrossRef] [PubMed]

87. Liu, T.L.; Newton, L.; Liu, M.-J.; Shiu, S.-H.; Farré, E.M. A G-Box-Like Motif Is Necessary for Transcriptional Regulation by Circadian Pseudo-Response Regulators in Arabidopsis. Plant Physiol. 2016, 170, 528-539. [CrossRef] [PubMed]

88. Liu, T.; Carlsson, J.; Takeuchi, T.; Newton, L.; Farré, E.M. Direct regulation of abiotic responses by the Arabidopsis circadian clock component PRR7. Plant J. Cell Mol. Biol. 2013, 76, 101-114. [CrossRef]

89. Kolmos, E.; Chow, B.Y.; Pruneda-Paz, J.L.; Kay, S.A. HsfB2b-mediated repression of PRR7 directs abiotic stress responses of the circadian clock. Proc. Natl. Acad. Sci. USA 2014, 111, 16172-16177. [CrossRef]

90. Swindell, W.R.; Huebner, M.; Weber, A.P. Transcriptional profiling of Arabidopsis heat shock proteins and transcription factors reveals extensive overlap between heat and non-heat stress response pathways. BMC Genomics 2007, 8, 125. [CrossRef]

91. Mittal, D.; Chakrabarti, S.; Sarkar, A.; Singh, A.; Grover, A. Heat shock factor gene family in rice: Genomic organization and transcript expression profiling in response to high temperature, low temperature and oxidative stresses. Plant Physiol. Biochem. 2009, 47, 785-795. [CrossRef]

92. Sharma, A.; Wai, C.M.; Ming, R.; Yu, Q. Diurnal Cycling Transcription Factors of Pineapple Revealed by Genome-Wide Annotation and Global Transcriptomic Analysis. Genome Biol. Evol. 2017, 9, 2170-2190. [CrossRef] [PubMed]

93. Pruneda-Paz, J.L.; Breton, G.; Nagel, D.H.; Kang, S.E.; Bonaldi, K.; Doherty, C.J.; Ravelo, S.; Galli, M.; Ecker, J.R.; Kay, S.A. A genome-scale resource for the functional characterization of Arabidopsis transcription factors. Cell Rep. 2014, 8, 622-632. [CrossRef] [PubMed]

94. Hirsch, S.; Oldroyd, G.E.D. GRAS-domain transcription factors that regulate plant development. Plant Signal. Behav. 2009, 4, 698-700. [CrossRef] [PubMed]

95. Li, J.; Han, G.; Sun, C.; Sui, N. Research advances of MYB transcription factors in plant stress resistance and breeding. Plant Signal. Behav. 2019, 14, 1613131. [CrossRef]

96. Torres-Galea, P.; Huang, L.-F.; Chua, N.-H.; Bolle, C. The GRAS protein SCL13 is a positive regulator of phytochrome-dependent red light signaling, but can also modulate phytochrome A responses. Mol. Genet. Genomics MGG 2006, 276, 13-30. [CrossRef]

97. Torres-Galea, P.; Hirtreiter, B.; Bolle, C. Two GRAS proteins, SCARECROW-LIKE21 and PHYTOCHROME A SIGNAL TRANSDUCTION1, function cooperatively in phytochrome A signal transduction. Plant Physiol. 2013, 161, 291-304. [CrossRef]

98. El-Kereamy, A.; Bi, Y.-M.; Ranathunge, K.; Beatty, P.H.; Good, A.G.; Rothstein, S.J. The rice R2R3-MYB transcription factor OsMYB55 is involved in the tolerance to high temperature and modulates amino acid metabolism. PloS ONE 2012, 7, e52030. [CrossRef] 
99. Casaretto, J.A.; El-Kereamy, A.; Zeng, B.; Stiegelmeyer, S.M.; Chen, X.; Bi, Y.-M.; Rothstein, S.J. Expression of OsMYB55 in maize activates stress-responsive genes and enhances heat and drought tolerance. BMC Genomics 2016, 17, 312. [CrossRef]

100. Adams, S.; Grundy, J.; Veflingstad, S.R.; Dyer, N.P.; Hannah, M.A.; Ott, S.; Carré, I.A. Circadian control of abscisic acid biosynthesis and signalling pathways revealed by genome-wide analysis of LHY binding targets. New Phytol. 2018. [CrossRef]

101. Sakuma, Y.; Maruyama, K.; Qin, F.; Osakabe, Y.; Shinozaki, K.; Yamaguchi-Shinozaki, K. Dual function of an Arabidopsis transcription factor DREB2A in water-stress-responsive and heat-stress-responsive gene expression. Proc. Natl. Acad. Sci. USA 2006, 103, 18822-18827. [CrossRef]

102. Sakuma, Y.; Maruyama, K.; Osakabe, Y.; Qin, F.; Seki, M.; Shinozaki, K.; Yamaguchi-Shinozaki, K. Functional analysis of an Arabidopsis transcription factor, DREB2A, involved in drought-responsive gene expression. Plant Cell 2006, 18, 1292-1309. [CrossRef] [PubMed]

103. Schramm, F.; Larkindale, J.; Kiehlmann, E.; Ganguli, A.; Englich, G.; Vierling, E.; von Koskull-Döring, P. A cascade of transcription factor DREB2A and heat stress transcription factor HsfA3 regulates the heat stress response of Arabidopsis. Plant J. Cell Mol. Biol. 2008, 53, 264-274. [CrossRef] [PubMed]

104. Cui, M.; Zhang, W.; Zhang, Q.; Xu, Z.; Zhu, Z.; Duan, F.; Wu, R. Induced over-expression of the transcription factor OsDREB2A improves drought tolerance in rice. Plant Physiol. Biochem. PPB 2011, 49, 1384-1391. [CrossRef] [PubMed]

105. Matsukura, S.; Mizoi, J.; Yoshida, T.; Todaka, D.; Ito, Y.; Maruyama, K.; Shinozaki, K.; Yamaguchi-Shinozaki, K. Comprehensive analysis of rice DREB2-type genes that encode transcription factors involved in the expression of abiotic stress-responsive genes. Mol. Genet. Genomics MGG 2010, 283, 185-196. [CrossRef]

106. Yang, S.; Xu, K.; Chen, S.; Li, T.; Xia, H.; Chen, L.; Liu, H.; Luo, L. A stress-responsive bZIP transcription factor OsbZIP62 improves drought and oxidative tolerance in rice. BMC Plant Biol. 2019, 19, 260. [CrossRef]

107. Das, P.; Lakra, N.; Nutan, K.K.; Singla-Pareek, S.L.; Pareek, A. A unique bZIP transcription factor imparting multiple stress tolerance in Rice. Rice N. Y. N 2019, 12, 58. [CrossRef]

108. Liao, Y.; Zou, H.-F.; Wei, W.; Hao, Y.-J.; Tian, A.-G.; Huang, J.; Liu, Y.-F.; Zhang, J.-S.; Chen, S.-Y. Soybean GmbZIP44, GmbZIP62 and GmbZIP78 genes function as negative regulator of ABA signaling and confer salt and freezing tolerance in transgenic Arabidopsis. Planta 2008, 228, 225-240. [CrossRef]

109. Oh, S.-J.; Song, S.I.; Kim, Y.S.; Jang, H.-J.; Kim, S.Y.; Kim, M.; Kim, Y.-K.; Nahm, B.H.; Kim, J.-K. Arabidopsis CBF3/DREB1A and ABF3 in transgenic rice increased tolerance to abiotic stress without stunting growth. Plant Physiol. 2005, 138, 341-351. [CrossRef]

110. Ezer, D.; Jung, J.-H.; Lan, H.; Biswas, S.; Gregoire, L.; Box, M.S.; Charoensawan, V.; Cortijo, S.; Lai, X.; Stöckle, D.; et al. The evening complex coordinates environmental and endogenous signals in Arabidopsis. Nat. Plants 2017, 3, 17087. [CrossRef]

111. Suzuki, N.; Bajad, S.; Shuman, J.; Shulaev, V.; Mittler, R. The transcriptional co-activator MBF1c is a key regulator of thermotolerance in Arabidopsis thaliana. J. Biol. Chem. 2008, 283, 9269-9275. [CrossRef]

112. Suzuki, N.; Sejima, H.; Tam, R.; Schlauch, K.; Mittler, R. Identification of the MBF1 heat-response regulon of Arabidopsis thaliana. Plant J. Cell Mol. Biol. 2011, 66, 844-851. [CrossRef] [PubMed]

113. Godfray, H.C.J.; Beddington, J.R.; Crute, I.R.; Haddad, L.; Lawrence, D.; Muir, J.F.; Pretty, J.; Robinson, S.; Thomas, S.M.; Toulmin, C. Food Security: The Challenge of Feeding 9 Billion People. Science 2010, 327, 812-818. [CrossRef] [PubMed]

114. Long, S.P.; Ort, D.R. More than taking the heat: crops and global change. Curr. Opin. Plant Biol. 2010, 13, 241-248. [CrossRef] [PubMed]

(C) 2020 by the authors. Licensee MDPI, Basel, Switzerland. This article is an open access article distributed under the terms and conditions of the Creative Commons Attribution (CC BY) license (http://creativecommons.org/licenses/by/4.0/). 